\title{
DIRASAH
}

Volume 3, Number 1, Februari 2020

p-ISSN: 2615-0212 | e-ISSN: 2621-2838

https://ejournal.iaifa.ac.id/index.php/dirasah

\begin{tabular}{|c|c|c|}
\hline Accepted: & Revised: & Published: \\
Nopember 2019 & Januari 2020 & Februari 2020 \\
\hline
\end{tabular}

\section{Sepuluh Faktor Agar Menjadi Guru yang Dicintai Oleh Siswanya}

\author{
Yazidul Busthomi \\ IAI Al-Qolam Gondanglegi Malang \\ e-mail: busthomi@alqolam.ac.id
}

\begin{abstract}
Becoming a teacher is truly noble work. He is responsible for not only making human children smart in the field of science but also good morals in this life. A human child who at first did not understand anything, before a teacher was educated to understand life better and know the world. On his shoulders is the duty and responsibility of the future survival of more intelligent and confronting generations. So noble the work of a teacher and how heavy the duties and responsibilities of being a teacher. This is why not everyone can become a successful teacher. Only certain people who have a love for children or students and are highly dedicated to the world of education are able to become a teacher. This is the personality of a teacher who is both teachings and educating in front of his students, the figure of a favorite teacher who is loved by his students. The ten factors for becoming a teacher that is loved by their students are as follows: 1 . Close to students, 2. Building a pleasant atmosphere, 3. Being able to act as a second parent, 4. Being friends in learning, 5. Personality deserves to be copied, 6 Be affectionate, 7. Be patient in teaching, 8. Can make laugh, 9. Liberator for students, 10. I can be a listener and mediator.
\end{abstract}

Keywords: Teacher, Love, Student 


\section{Abstraksi}

Menjadi seorang guru adalah pekerjaan yang sungguh mulia. Dia bertanggung jawab tidak hanya membuat anak manusia pintar di bidang ilmu pengetahuan, tetapi juga moral yang baik dalam kehidupan ini. Seorang anak manusia yang pada mulanya tidak mengerti apa-apa, sebelum seorang guru dididik untuk memahami hidup lebih baik dan mengenal dunia. Di pundaknya adalah tugas dan tanggung jawab dari kelangsungan hidup masa depan yang lebih cerdas dan menghadapi generasi. Begitu mulia pekerjaan seorang guru dan betapa beratnya tugas dan tanggung jawab menjadi seorang guru. Ini adalah mengapa tidak semua orang bisa menjadi guru yang sukses. Hanya orang tertentu yang memiliki kecintaan pada anak atau siswa dan sangat berdedikasi pada dunia pendidikan yang maтрu menjadi guru. Ini adalah kepribadian dari seorang guru yang mengajar dan mendidik di depan murid-muridnya, sosok seorang guru favorit yang dicintai oleh murid-muridnya. Sepuluh faktor untuk menjadi guru yang dicintai oleh siswa mereka adalah sebagai berikut: 1. dekat dengan siswa, 2. membangun suasana yang menyenangkan, 3. mampu bertindak sebagai orangtua kedua, 4. berteman dalam belajar, 5. kepribadian layak untuk disalin, 6 menjadi kasih sayang 7. Bersabar dalam mengajar, 8. Bisa membuat tertawa, 9. Liberator bagi siswa, 10. Bisa menjadi pendengar dan mediator.

\section{Keywords: guru, cinta, siswa}

\section{Pendahuluan}

Dalam dunia pendidikan tidak hanya keluarga yang merupakan faktor utama pendidikan terhadap anak, akan tetapi guru di lembaga sekolah sangat diutamakan dalam mendidik anak didiknya. Guru sebagai subyek yang melaksanakan pendidikan, karena guru mempunyai peranan penting untuk berlangsungnya pendidikan, baik atau tidaknya guru berpengaruh besar terhadap hasil pendidikan bagi peserta didik yang merupakan obyek terpenting dalam pendidikan. Hal ini disebabkan perbuatan atau tindakan mendidik itu diadakan atau dilakukan hanyalah untuk membawa peserta didik kepada tujuan pendidikan yang dicita-citakan.

Anak adalah amanah Allah dan harus dijaga dan dididik untuk mencapai keutamaan dalam hidup dan mendekatkan diri kepada Allah, kedua orang tuanyalah yang akan mengukir dan membentuknya menjadi mutiara yang berkualitas tinggi dan disenangi semua orang karena semua bayi yang dilahirkan kedunia ini, bagaikan sebuah mutiara yang belum diukur dan belum berbentuk tapi amat bernilai tinggi. Maka ketergantungan anak kepada pendidiknya termasuk kepada kedua orang tuanya, tampak sekali.

Usia dini pada kebanyakan manusia memiliki rangsangan dan daya tangkap yang sangat peka terhadap pendidikan. Pendidikan yang harus dialami dan 
dilakukan oleh manusia adalah pendidikan yang berlangsung seumur hidup, dengan kata lain pendidikan tidak hanya pada usia dini. Maka proses belajar itu bagi seseorang dapat terus berlangsung dan tidak terbatas pada dunia sekolah saja. Esensi pendidikan agama Islam terletak pada kemampuannya untuk mengembangkan potensi anak agar menjadi manusia yang beriman dan bertakwa dan dapat tampil sebagai khalifatullah fi al-ardh. Esensi ini menjadi acuan terhadap metode pembelajaran untuk mencapai tujuan yang maksimal. ${ }^{1}$

Pendidikan adalah suatu aktivitas untuk mengembangkan seluruh aspek kepribadian manusia yang berjalan seumur hidup. ${ }^{2}$ Pendidikan pada hakikatnya adalah pengembangan potensi atau kemampuan manusia secara menyeluruh yang pelaksanaannya dilakukan dengan cara mengajarkan pelbagai pengetahuan dan kecakapan yang dibutuhkan oleh manusia itusendiri. ${ }^{3}$ Pendidikan adalah bimbingan atau pimpinan secara sadar oleh pendidik terhadap perkembangan jasmani dan rohani anak didik menuju terbentuknya kepribadian yang utama

Definisi di atas telah menunjukkan bahwa pendidikan adalah suatu cara untuk mendidik seorang agar mencapai tujuan tertentu dalam pendidikan itu sendiri. Begitu juga dengan pendidikan menurut Islam yaitu bimbingan yang diberikan kepada orang lain agar berkembang sesuai dengan dasar-dasar ajaran Islam. Sebab dalam pendidikan Islam terkandung arahan yang menunjukkan terhadap perbaikan sikap mental dan tingkah laku yang sesuai dengan ajaran Islam baik itu untuk diri sendiri maupun orang lain. Dari sini dapat dijelaskan bahwa pendidikan dalam Islam ialah bimbingan seorang pendidik terhadap anak didik sesuai dengan ajaran Islam agar menjadi seorang muslim yang seutuhnya.

Dalam dunia pendidikan guru sebagai pendidik harus berakhlakul karimah, karena pendidik adalah seorang penasehat bagi anak didiknya. Dengan berakhlak mulia, dalam keadaan bagaimanapun pendidik harus memiliki rasa percaya diri, istiqomah dan tidak tergoyahkan. Kepribadian pendidik yang dilandasi dengan akhlak mulia tentu saja tidak tumbuh dengan sendirinya, tetapi memerlukan usaha sungguh-sungguh, kerja keras, tanpa mengenal lelah dan dengan niat ibadah. Untuk menjadi teladan bagi anak didiknya, tentu saja pribadi dan apa yang dilakukan oleh

1 Ismail, Strategi Pembelajaran Agama Islam Berbasis PAIKEM, cetakan IV (Semarang: Rasail Media Group, 2009), 3.

${ }^{2}$ Zuhairini., Filsafat Pendidikan Islam, cetakan II (Jakarta: Bumi Aksara, 1995), 149.

3 Muhibbin Syah, Psikologi Pendidikan dengan Pendekatan Baru, cetakan XIV (Bandung: PT

Remaja Rosdakarya, 2008), 35.

Dirasah, Vol. 3, No. 1, Februari 2020 
seorang pendidik akan mendapat sorotan dari anak didiknya serta orang di sekitar lingkungannya yang menganggap atau mengakuinya sebagai pendidik.

Tugas dan tanggung jawab seorang guru sesungguhnya sangat berat. Di pundaknyalah tujuan pendidikan secara umum dapat tercapai atau tidak. Mengapa di pundak seorang guru dan bagaimana dengan tugas dan tanggung jawab orangtua anak didik yang mendapatkan amanat langsung dari Allah?Pertanyaan penting ini harus dijawab terlebih dulu sebelum membahas persoalan ini lebih jauh.Orangtua memang mendapat amanat/tugas langsung dari Allah untuk mendidik anakanaknya. Di hadapan Allah kelak para orangtua juga akan dimintai pertanggungjawaban tentang cara mereka mendidik anak-anaknya. Namun, karena kemampuan, pengetahuan, dan waktu yang dimiliki oleh orangtua terbatas, sebagian besar orangtua memercayakan pendidikan anak-anaknya kepada gurugurunya di sekolah.

Tugas dan tanggungjawab seorang guru di sekolah/madrasah semakin berat karena tidak sedikit dari orangtua yang seakan mempercayakan sepenuhnya pendidikan anak-anaknya di sekolah. Mereka beranggapan bahwa tugas dan tanggungjawab orangtua adalah bekerja dan bekerja sehingga mempunyai uang yang banyak untuk memenuhi kebutuhan anak-anaknya, termasuk biaya sekolah. Bahkan, tidak sedikit orangtua yang berusaha dengan sekuat tenaga agar anakanaknya dapat sekolah di tempat yang favorit meskipun biayanya mahal.Orangtua yang demikian biasanya telah merasa bahwa tugas dan tanggungjawabnya di bidang pendidikan anak-anaknya telah selesai. Mereka percaya sepenuhnya bahwa pihak sekolah telah mendidiknya dengan baik sehingga merasa tidak perlu lagi mengontrol pendidikan anaknya ketika di rumah. Sungguh, anggapan yang seperti itu tidaklah benar. Orangtua tetap bertanggungjawab terhadap pendidikan anakanaknya secara keseluruhan. Sedangkan, guru bertanggungjawab karena mendapatkan amanat dari orangtua untuk mendidik anak-anak mereka, di samping merupakan tanggungjawab kemanusiaan. ${ }^{4}$

Disinilah sesungguhnya tugas dan tanggungjawab guru menjadi tidak mainmain. Amanat dari orang tua untuk mendidik anak-anaknya mesti ditunaikan dengan sangat baik. Guru tidak sekedar mengajar, tetapi juga mendidik anak didiknya. Dengan demikian, seorang guru bisa dikatakan sebagai orang tua kedua bagi anak didiknya. Sebagai orangtua kedua, sudah tentu dibutuhkan kedekatan

\footnotetext{
${ }^{4}$ Akhmad Muhaimin Azzet, Menjadi Guru Favorit, cetakan I (Jogjakarta: Ar-Ruzz Media, 2011), 18.
} 
dengan anak didiknya agar berhasil dalam menjalankan tugas penting dan mulia ini.

Kedekatan dengan anak didik adalah kunci penting bagi seorang guru bila ingin sukses dalam menjalankan tugas dan tanggungjawabnya. Tanpa kedekatan, tugas dan tanggungjawab itu akan sulit dapat terlaksana dengan baik karena anak didik bukanlah robot yang siap menerima program apa pun dari orang yang membuat atau mengoperasikannya. Anak didik adalah pribadi yang mempunyai jiwa. Sudah tentu, menghadapi pribadi yang mempunyai jiwa dibutuhkan kedekatan di antara dua jiwa agar komunikasi dalam proses pembelajaran dapat berjalan dengan baik.

Menjadi guru adalah pekerjaan yang sungguh mulia. Ia bertanggungjawab tidak hanya menjadikan para anak manusia pandai di bidang ilmu pengetahuan, tetapi juga bermoral baik dalam kehidupan ini. Seorang anak manusia yang pada mulanya tidak mengerti apa-apa, di hadapan seorang guru dididik untuk memahami kehidupan secara lebih baik dan mengenal dunia. Di pundaknyalah ada tugas dan tanggungjawab keberlangsungan masa depan generasi yang lebih cerdas dan berperadapan.

Begitu mulia pekerjaan seorang guru sekaligus betapa berat tugas dan tanggungjawab menjadi seorang guru. Inilah mengapa tidak semua orang bisa menjadi seorang guru yang berhasil. Hanya orang-orang tertentu yang mempunyai rasa cinta terhadap anak-anak atau peserta didik dan berdedikasi tinggi terhadap dunia pendidikan saja yang mampu menjadi seorang guru. Inilah pribadi seorang guru yang berhasil mengajar sekaligus mendidik di hadapan murid-muridnya, sosok seorang guru favorit yang dicintai oleh anak didiknya.

Motivasi dan kecintaan seseorang untuk menjadi guru adalah dasar bagi seorang guru akan sukses dan dicintai oleh murid-muridnya atau tidak. Motivasi dan kecintaan ini harus terpancang sejak awal seseorang menekuni profesi sebagai guru atau bisa pula baru terbangunkan setelah seseorang menjalani profesi ini sekian waktu.Motivasi dan kecintaan ini harus senantiasa dijaga agar seorang tetap bersemangat menghadapi anak didiknya dalam proses pembelajaran. Jadi, motivasi dan kecintaan ini semacam ruh bagi seorang guru agar selalu dekat dengan anak didiknya sehingga apa yang disampaikan dalam pembelajaran mudah diterima. Inilah kunci penting bagi keberhasilan seorang guru dalam menjalankan tugas dan tanggungjawabnya. Seorang guru yang tidak hanya mencintai profesinya, tetapi juga dicintaioleh anak didiknya. 
Menjadi guru yang mencintai profesi dan dicintai oleh anak didik betapa membahagiakan hati. Sebaliknya, menjadi guru yang sekadar sebagai profesi, biasanya juga akan sekadar dikenal saja oleh anak didiknya secara pribadi. Dalam hubungan yang semacam ini, terasa sekali tiada kedekatan antar-pribadi. Bila hal ini yang terjadi, proses pembelajaran akan berjalan datar-datar saja, serasa hambar, bahkan tidak jarang menjemukan.

\section{Kompetensi Guru}

Kompetensi adalah suatu hal yang menggambarkan kualifikasi atau kemampuan seseorang. Kompetensi adalah seperangkat tindakan inteligen penuh tanggung jawab yang harus dimiliki seseorang sebagai syarat untuk dianggap mampu melaksanakan tugas-tugas dalam bidang pekerjaan tertentu. Depdiknas merumuskan definisi kompetensi sebagai pengetahuan, keterampilan dan nilai-nilai dasar yang direfleksikan dalam kebiasaan berpikir dan bertindak. ${ }^{5}$

Guru sebagai pendidik atau pun mengajar merupakan faktor penentu kesuksesan setiap usaha pendidikan. Itulah sebabnya setiap perbincangan mengenai pembaharuan kurikulum, pengadaan alat-alat belajar sampai pada kriteria sumber daya manusia yang dihasilkan oleh usaha pendidikan selalu bermuara pada guru. Hal ini menunjukkan betapa signifikasi posisi guru dalam pendidikan. ${ }^{6}$

Guru yang dimaksud dalam pembahasan ini ialah guru profesional yang wajib memiliki komitmen untuk meningkatkan mutu pendidikan. Kegiatan mengajar yang dilakukan guru itu tidak hanya berorientasi pada kecakapankecakapan berdimensi ranah cipta saja tetapi kecakapan yang berdimensi ranah rasa dan karsa. Sebab mengajar pada prinsipnya berarti proses perbuatan seorang guru yang membuat orang lain belajar, dalam arti mengubah seluruh dimensi prilakunya. Mengajar pada hakikatnya sama dengan mendidik. Karena itu, tidak perlu heran bila seorang guru yang sehari-harinya sebagai pengajar lazim juga disebut pendidik.

Guru profesional adalah orang yang memiliki kemampuan dan keahlian khusus dalam bidang keguruan sehingga ia mampu melakukan tugas dan fungsinya sebagai guru dengan kemampuan maksimal. Atau dengan kata lain, guru

\footnotetext{
${ }^{5}$ Abdul Majid, Perencanaan Pembelajaran, cetakan VI (Bandung: PT Remaja Rosdakarya, 2009), 5.

${ }^{6}$ Muhibbin Syah, Psikologi Pendidikan dengan Pendekatan Baru, cetakan XIV (Bandung: PT Remaja Rosdakarya, 2008), 223
}

Dirasah, Vol. 3, No. 1, Februari 2020 
profesional adalah orang yang terdidik dan terlatih dengan baik, serta memiliki pengalaman yang kaya di bidangnya. ${ }^{7}$

Yang dimaksud dengan terdidik dan terlatih bukan hanya memperoleh pendidikan formal tetapi juga harus menguasai berbagai strategi atau teknik di dalam kegiatan pembelajaran serta menguasai landasan-landasan kependidikan.Kompetensi guru meliputi kompetensi pedagogik, kompetensi kepribadian, kompetensi sosial dan kompetensi profesional yang diperoleh melalui pendidikan profesi. Kompetensi guru adalah kemampuan dan kewenangan guru dalam melaksanakan profesinya.Mengingat tugas dan tanggungjawab guru yang begitu kompleksnya, maka seorang guru yang profesional dituntut untuk memiliki beberapa kompetensi khusus yaitu:

\section{Kompetensi Pedagogik}

Kompetensi pedagogik adalah kemampuan guru dalam pengelolaan pembelajaran peserta didik yang sekurang-kurangnya meliputi:

1) Pemahaman wawasan atau landasan kependidikan.

2) Pemahaman terhadap peserta didik.

3) Pengembangan kurikulum atau silabus.

4) Perencanaan pembelajaran.

5) Pelaksanaan pembelajaran yang mendidik dan dialogis.

6) Pemanfaatan teknologi pembelajaran.

7) Evaluasi hasil balajar.

8) Pengembangan peserta didik untuk mengaktualisasikan berbagai potensi yang dimilikinya.

\section{Kompetensi Kepribadian}

Kompetensi kepribadian adalah kemampuan kepribadian yang sekurangkurangnya mencakup kepribadian yang:

1) Beriman dan bertakwa.

2) Berakhlak mulia.

3) Arif dan bijaksana.

4) Demokratis.

5) Mantap.

6) Berwibawa.

7) Stabil.

8) Dewasa.

\footnotetext{
${ }^{7}$ Moh. Uzer Usman, Menjadi Guru Profesional, cetakan XX111 (Bandung: PT Remaja Rosdakarya, 2009), 15.
}

Dirasah, Vol. 3, No. 1, Februari 2020 
9) Jujur.

10) Sportif.

11) Menjadi teladan bagi peserta didik dan masyarakat.

12) Secara obyektif mengevaluasi kinerja sendiri.

13) Mengembangkan diri secara mandiri dan berkelanjutan.

\section{Kompetensi Profesional}

Kompetensi profesional adalah kemampuan guru dalam menguasai pengetahuan bidang ilmu pengetahuan, teknologi, dan/atau seni dan budaya yang diampunya yang sekurang-kurangnya meliputi penguasaan:

1) Materi pembelajaran secaraluas dan mendalam sesuai dengan standar isi program satuan pendidikan, mata pelajaran, dan/atau kelompok mata pelajaran yang akan diampu.

2) Konsep dan metode disiplin keilmuan, teknologi atau seni yang relevan, yang secara konseptual menaungi atau koheren dengan program satuan pendidikan, mata pelajaran, dan/atau kelompok mata pelajaran yang akan diampu.

\section{Kompetensi Sosial}

Kompetensi sosial adalah kemampuan guru sebagai bagian dari masyarakat yang sekurang-kurangnya meliputi kompetensi untuk:

1) Berkomunikasi lisan, tulis, dan/atau isyarat secara santun.

2) Menggunakan teknologi komunikasi dan informasi secara fungsional.

3) Bergaul secara efektif dengan peserta didik, sesama pendidik, tenaga kependidikan, pimpinan satuan pendidikan, orang tua/wali peserta didik.

4) Bergaul secara efektif dengan masyarakat sekitar dengan mengindahkan norma serta sistem nilai yang berlaku.

5) Menerapkan prinsip persaudaraan sejati dan semangat kebersamaan.

\section{Konsepsi Tentang Anak Didik}

Secara kodrati anak memerlukan pendidikan atau bimbingan dari orang dewasa. Dasar kodrati ini dapat dimengerti dari kebutuhan-kebutuhan dasar yang dimiliki oleh setiap anak yang hidup di dunia ini. Kebutuhan yang harus dipenuhi serta berbagai potensi maupun diposisi untuk dididik, dibimbing dan diarahkan sehingga dapat mengaktualisasikan dirinya dalam kehidupan. Dan membentuk anak didik itu harus sesuai dengan tujuan pengajaran yang diharapkan maka pengajaran harus disesuaikan dengan keadaan dan tingkat kemampuan anak, karakteristik, minat dan lain sebagainya. Itulah sebabnya murid merupakan objek didik dalam pendidikan. 
Peserta didik adalah anggota masyarakat yang berusaha mengembangkan potensi diri melalui proses pembelajaran yang tersedia pada jalur, jenjang, dan jenis pendidikan tertentu. Ia adalah pelanggan utama mendapat pelayanan dalam proses pendidikan. Dengan perkataan lain proses pendidikan akan bermakna jika dilakukan oleh, dari, dan untuk peserta didik. Sehingga dari segala potensi yang dimiliki oleh seorang manusia dapat mengembangkan kepribadian diri dan orang lain menuju kesempurnaan (insal kamil). Perkembangan individu (peserta didik) disamping ditentukan oleh aspek dasar (fitrah) juga dipengaruhi oleh faktor ajar (lingkungan).

Pemenuhan kebutuhan peserta didik disamping bertujuaan untuk memberikan materi kegiatan setepat mungkin, juga materi pelajaran yang sudah disesuaikan dengan kebutuhan biasanya menjadi lebih menarik. Dengan demikian akan membantu pelaksanaan proses pembelajaran. Kebutuhan manusia dibedakan menjadi 2 yaitu:

1. Kebutuhan primer, yaitu kebutuhan jasmani seperti makan dan minum.

2. Kebutuhan sekunder, yaitu kebutuhan rohani.

Adapun yang menjadi kebutuhan peserta didik antara lain :

a. Kebutuhan Jasmani

Hal ini berkaitan dengan tuntutan peserta didik yang bersifat jasmaniah.

Diantaranya ruang kelas yang memadai dan sarana yang menunjang.

b. Kebutuhan Rohaniah

Hal ini berkaitan dengan pemenuhan kebutuhan peserta didik yang bersifat rohaniah, misalnya siswa merasa puas dengan segala penjelasan dari seorang guru karena penjelasanya memahamkan.

c. Kebutuhan Sosial

Pemenuhan keinginan untuk saling bergaul sesama peserta didik dan pendidik serta orang lain. Dalam hal ini sekolah harus dipandang sebagai lembagai tempat para peserta didikbelajar, beradaptasi, bergaul sesama teman yang berbeda jenis kelamin, suku bangsa, agama, status sosial dan kecakapan.

Pendidikan merupakan bimbingan dan pertolongan secara sadar yang diberikan oleh pendidik kepada anak didik sesuai dengan perkembangan jasmaniah dan rohaniah ke arah kedewasaan. Agar pendidikan dapat berhasil dengan sebaikbaiknya haruslah menempuh jalan pendidikan yang sesuai perkembangan anak didik. Anak didik di dalam mencari nilai hidup, harus dapat bimbingan sepenuhnya dari pendidik, karena menurut ajaran Islam, saat anak dilahirkan dalam keadaan 
fitrah/suci sedangkan alam sekitarnya akan memberi corak warna terhadap nilai hidup atas pendidikan agama anak didik. ${ }^{8}$

Dalam kitab maroqil ubudiyah yang menjadi syarah kitab bidayah alHidayah, Imam Muhammad Nawawi telah menerangkan tentang etika-etika anak didik terhadap pendidiknya yaitu sebagai berikut:

Memulai memberi salam dan minta izin masuk.

b). Sedikit bicara dihadapannya.

c). Tidak berbicara selama tidak ditanya oleh gurunya.

d). Tidak menanyakan sesuatu sebelum minta izin kepada gurunya lebih dulu.

e). Tidak menoleh ke kanan dan kekiri.

\section{Sepuluh Faktor agar Menjadi Guru yang Dicintai oleh Siswanya}

Sepuluh faktor agar menjadi guru yang dicintai oleh siswanya yaitu sebagai berikut:

\section{Dekat dengan Anak Didik}

Modal utama agar menjadi guru favorit atau dicintai oleh peserta didiknya yaituhubungan yang dekat dengan mereka. Kedekatan dengan anak didik ini bisa dibangun dengan kedekatan secara lahir maupun secara batin. Kedekatan antara guru dan anak didiknya mutlak diperlukan. Hal ini dianggap penting karena proses pembelajaran diyakini tidak akan berjalan dengan lancar dan berhasil secara maksimal tanpa adanya kedekatan antara yang mendidik dengan yang dididik. Dengan adanya kedekatan ini, diharapkan anak didik dapat mengikuti pelajaran yang disampaikan oleh gurunya dengan perasaan yang santai dan pikiran yang tenang. Lain halnya bila guru dan anak didiknya tidak ada jalinan hubungan kedekatan, biasanya proses pembelajaran akan berjalan dengan ketegangan, dengan demikian yang mudah pun bisa menjadi sulit dicerna.

Kedekatan antara guru dan peserta didik diperlukan agar peserta didik dapat belajar dengan baik, terutama ketika menghadapi materi pelajarannya yang sulit dipahami. Maka, peserta didik dapat bertanya tanpa rasa malu kepada gurunya. Tidak adanya peserta didik yang bertanya ketika proses pembelajaran berlangsung bukan selalu berarti semua peserta didik sudah memahami pelajaran yang dimaksud. Bisa jadi mereka enggan bertanya karena tidak adanya kedekatan dengan sang guru. Demikan pula dengan adanya kedekatan seorang guru dapat membantu masalah yang dihadapi oleh peserta didiknya sehingga

${ }^{8}$ Zuhairini., Filsafat Pendidikan Islam, cetakan II (Jakarta: Bumi Aksara, 1995), 170.

Dirasah, Vol. 3, No. 1, Februari 2020 
proses pembelajaran pun tetap berjalan dengan lancar sesuai dengan apa yang diharapkan, yaitu tujuan pendidikan dapat tercapai dengan maksimal.

Kedekatan secara lahir dapat dibangun denganbentuk perhatian yang diperlihatkan kepada peserta didiknya. Meski diperlihatkan, hal penting yang tidak boleh diabaikan hendaknya dilakukan dengan hati yang ikhlas karena setiap tindakan yang dimulai dari hati yang ikhlas akan menimbulkan energi positifyang luar biasa. Bentuk perhatian secara lahir, misalnya menyapa dengan ramah ketika betemu. Di samping seorang guru membangun kedekatan secara lahir, juga tidak kalah pentingnya untuk membangun kedekatan secara batin kepada anak didiknya. Kedekatan ini dapat dilakukan dengan mendokan secara khusus kepada peserta didiknya agar diberi kemudahan dalam belajar dan mencapai kesuksesan. Sungguh, cara ini sangat pening untuk dilakukan oleh seoang guru kepada peserta didiknya. Mendoakan tidak hanya dialakukan hanya sekali saja, tetapi bisa secara istiqamah/berkala, misalnya dilakukan setiap selesai shalat lima waktu dan di tengah malam ketika selesai shalat tahajud.

\section{Membangun Suasana yang Menyenangkan}

Orang yang pandai membangun suasana yang menyenangkan dalam sebuah hubungan, juga pasti akan disenangi oleh banyak orang. Demikian pula dengan guru hendaknya pandai membawa suasana yang menyenangkan dalam proses pembelajaran, sehingga disenangi oleh peserta didiknya. Penulis sering mengamati bahwa guru favorit adalah seorang guru yang menyenangkan. Siapa saja akan merasa senang bila berada dalam suasana yang menyenangkan, termasuk peserta didik ketika mengikuti proses pembelajaran yang menyenangkan, merekaakan merasa senang.

Seorang guru yang menyenangkan adalah seorang yang mempunyai kepribadian sebagai berikut:

\section{a. Memahami Kebutuhan Peserta Didik}

Guru yang dicintai oleh peserta didiknya adalah guru yang bisa memahami kebutuhan anak didinya dengan sangat baik. Orang yang demikian biasanya senantiasa mengedepankan dialog yang dianggap penting atau musyawarah terbuka, artinya tidak ada sesuatu yang disembunyikan. Dalam hal ini guru tersebut berusaha untuk mendengarkan apa yng menjadi kebutuhan peserta didiknya.

\section{b. Memberikan Penghargaan}

Seorang guru yang dicintai oleh peserta didiknya adalah yang bisa memberikan penghargaan kepada peserta didiknya.Penghargaan bisa 
diberikan dengan kata-kata yang baik dan bermanfaat. Misalnya, pada saat seorang peserta didik berhasil mengerjakan pekerjaannya, seorang guru berkomentar, "bagus sekali." Sudah tentu, sang anak didik akan merasa senang dan memuaskan karena mendapat penghargaan dari gurunya.

\section{c. Dapat Mengontrol Emosi dengan Baik}

Menjadi guru tidak selalu menghadapi peserta didik yang baik, sopan, taat, tertib, dan tepat waktu. Ada saja dari peserta didik yang justru sikapnya memancing kemarahan gurunya. Maka, guru yang tidak bisa mengontrol emosinya dengan baik, terpancing untuk memarahi peserta didiknya. Berbeda dengan seorang guru yang dapat mengontrol emosinya dengan baik. Jika ada di antara peserta didik yang melakukan perbuatan yang melanggar dari aturan sekolah, ia mencoba untuk memahami mengapa anak tersebut melakukan perbuatan tersebut. Sang guru akan dengan lembut memanggil anak tersebut lantas menanyainya dengan baik.

\section{Bisa Berperan sebagai Orangtua Kedua}

Guru yang bisa berperan sebgai orangtua kedua bagi anak didiknya ketika berada di sekolah, maka guru tersebut akan dicintai oleh anak didiknya. Seorang guru yang dicintai oleh anak didiknya, menjadi modal untuk dapat dikatakan sebagai guru favorit. Anak didik adalah pribadi yang sesungguhnya masih membutuhkan kasih sayang dan teladan yang baik dalam masa perkembangan jiwanya. Di sinilah mereka sangat membutuhkan dari kedua orang tuanya dalam kehidupan sehari-harinya ketika berada di rumah. Selain di rumah, lingkungan kedua bagi anak didik adalah berada disekolah, disinilah anak didik juga membutuhkan orang yang bisa memberikan kasih sayang dan teladan yang baik, yaitu dari gurunya.

\section{a. Membangun Rasa Kasih Sayang}

Rasa kasih sayang yang perlu dibangun adalah rasa kasih sayang sebagaimana orangtua kepada anaknya. Karena seorang guru bukanlah orangtua kandung bagi nak didiknya, sudah tentu ekspresi dan bentuknya berbeda dengan orangtua kandung mereka dalam memberikan rasa kasih sayang. Rasa ksih sayang yang bersumber dari dalam hati tetaplah perlu dibangun dengan sebaik-baiknya oleh seorang guru yang ingin dicintai oleh anak didiknya, sebagaimana anak mencintai oarng tuanya sendiri.

\section{b. Memberiakan yang Terbaik}

Setiap orangtua ingin memberikan yang terbaik untuk anak-anaknya. Untuk memberikan yang terbaik ini, orangtua bekerja dan berusaha dengan 
sekuat tenaga. Semua ini dilakukan agar anaknya tumbuh dan berkembang dalam asuhan yang menyenangkan dan dapat meraih keberhasilan dalam dunia pendidikan, baik pendidikan dalam keluarga maupun pendidikan di lembaga sekolah. Disinilah alasan orangtua dicintai dan dihormati denagn setulusnya oleh anak-anaknya. Guru sebagai orangtua kedua bagi anak didik ketika berada di lingkungan sekolah, maka ia harus senantiasa membangun kesadarannya untuk bisa memberikan yang terbaik kepada anak didiknya, sebagaimana orangtua memberikan yang terbaik kepada anaknya sendiri.

\section{c. Mendampingi dengan Senang Hati}

Salah satu kelebihan orangtua terhadap anak-anaknya adalah mendampingi dengan senang hati dalam proses tumbuh dan berkembangnya. Oleh karena itu, anak merasakan nyaman dan damai ketika berada di samping orang tuanya. Meski bukan orangtua kandung, apabila seorang guru dapat membangun kepedulian yang kuat dalam hatinya untuk bisa senantiasa mendampingi anak didiknya dengan senang hati. Maka, seoarng guru tersebut akan disenangi oleh anak didiknya, karena ia mendampingi mereka dengan senang hati.

\section{Menjadi Sahabat dalam Belajar}

Guru yang dicintai oleh anak didiknya adalah yang bisa menjadi sahabat dalam belajar. Guru yang menjadi sahabat ini adalah hal baru dan penting untuk diperhatikan. Peran seorang guru adalah memberikan ilmu kepada anak didiknya. Oleh karena itu,seorang guru akhirnya juga menjadi penguasa tunggal di dalam kelas. Sebagai penguasa tunggal di dalam kelas, seorang guru di zaman dahulu bebas melakukan apa saja, termasuk dalam memberikan hukuman kepada peserta didiknya. Sang anak pun enggan mengadukan perlakuan sang guru tersebut ke orangtuanya. Sebab orangtuanya pun biasanya malah menyalakan anak sendiri yang dituduh tidak patuh pada gurunya. ${ }^{9}$

di zaman sekarang, sangat mudahnnya akses ilmu pengetahuan, seorang guru yang disenangi peserta didik adalah guru yang dapat menjadi sahabat dalam belajar dan memahami kehidupan yang terus berkembang. Guru yang menempatkan diri sebagai seorang sahabat akan membuat peserta didik merasa dekat dan nyaman. Kedekatan dan rasa nyaman ini sungguh penting kaitannya dengan motivasi dan semangat peserta didik dalam proses pembelajarannya.

\footnotetext{
${ }_{9}^{9}$ Akhmad Muhaimin Azzet, Menjadi Guru Favorit, cetakan I (Jogjakarta: Ar-Ruzz Media, 2011), 50 .
} 
Peserta didik yang merasakan hubungan dengan gurunya yang tidak kaku, dekat dan penuh persahabatan akan merasakan bahwa belajar di sekolah itu hal yang menyenangkan. Bila peserta didik telah merasakan kesenangan dalam belajar, tentu ia akan bersemangat ketika berada di sekolah. Demikian pula ketika belajar di rumah yang biasanya dilakukan untuk membaca kembali pelajaran di sekolah atau mengerjakan PR dari gurunya di sekolah. Bila hal ini telah terjadi, tujuan proses pembelajaran akan lebih mudah tercapai.

di zaman sekarang, seorang guru bukanlah satu-satunya sumber ilmu pengetahuan, bahkan ada sumber pengetahuan yang lebih mudah di akses. Oleh karena itu, menjadikan peserta didik sebagai sahabat adalah pilihan cerdas bagi seorang guruyang ingin dicintai oleh anak didiknya. Seorang guru yang tampil sebagai sahabat bagi peserta didiknya tentu akan menjadikan pribadinya hangat dan penuh keakraban dengan anak didiknya. Seorang guru yang tampil penuh persahabatan dengan anak didiknya tentu bukan guru yang begitu mudah menjatuhkan hukuman bagi anak didik yang melanggar. Apalagi, langsung memberikan hukuman tanpa bertanya sebelumnya kepada anak didiknya mengapa melakukan hal yang tidak baik. Akan tetapi bukan berarti seorang guru tidak boleh memberikan hukuman, jika ada di antara peserta didiknya melakukan pelanggaran, tentu tidak boleh dibiyarkan begitu saja.

\section{Berkepribadian Layak Ditiru}

Seorang guru yang dicintai oleh anak didiknya adalah guru yang mempunyai kepribadian layak ditiru. Inilah kepribadian utama yang harus dimiliki oleh seorang guru. Menurut falsafah jawa, kata guru berasal dari kalimat "bisa digugu (dipercaya) dan ditiru (dicontoh)". Jadi, orang yang menjadi guru adalah seorang yang bisa dipercaya dan ditiru tingkah lakunya oleh anak didiknya. Dua hal sebagaimana tersebut, yaitu bisa dipecaya dan layak ditiru, adalah modal utama bagi siapa saja yang ingin berkepribadian unggul. Bagi seorang guru yang memang pekerjaannya mendidik para peserta didiknya agar pandai di bidang ilmu pengetahuan dan mempunyai budi pekerti yang luhur. sudah tentu, tidak bisa tidak, ia harus bisa dipercaya dan bisa ditiru oleh anak didiknya.

Sebagai guru yang bertanggung jawab, tentu tidak ingin apa yang dilakukannya terkait dengan proses pembelajaran mengalami kegagalan. Meskipun kita tidak menutup mata, masih ada juga guru yang mempunyai kepribadian yang tidak bisa dipercaya dan tidak bisa untuk dijadikan contoh atau teladan tingkah lakunya. Meskipun demikian, masih banyak guru yang mencoba 
untuk terus memperbaiki diri. Bila seorang guru telah mampu menata diri dan menunjukkan bahwa ia layak dipercaya dan bisa dijadikan contoh bagi anak didiknya, ia akan dicintai oleh anak-anak didiknya, bahkan hingga anak didiknya lulus sekolah. Ada tiga modal uatama yang dapat dilakukan oleh seorang guru agar mempunyai kepribadian yang layak ditiru dan dicintai oleh peserta didiknya:

a. Sesuainya kata dan perbuatan

b. Menyadari kedudukannya sebagai seorang guru

c. Terus belajar dan menambah ilmu pengetahuan

\section{Bersikap Kasih Sayang}

Seorang guruyang ingin dicintai oleh anak didiknya harus bisa memberikan kasih sayang kepada mereka. Kasih sayang ini besar pengruhnya dalam rangka mewujudkan keberhasilan peserta didik dalam menguasai standar kompetensi mata pelajarannya ketika proses pembelajaran.Kasih sayang diyakini menjadi sumber mata air kebijaksanan dalam semua sendi kehidupan, termasuk dalam dunia pendidikan, baik pendidikan dalam keluarga maupun pendidikan disekolah. Sikap seorang guru yang penuh dengan kasih sayang bisa menjadikan semangat tersendiri ketika ia menjalankan tugasnya sebagai guru yang profesional.

Ada tiga modal yang dapat dijadikan bahan pemikiran agar seorang guru dapat memberikan kasih sayang secara penuh kepada peserta didiknya:

\section{a. Kasih Sayang Membangkitkan Semangat}

Kasih sayang yang diberikan oleh seorang guru kepada peserta didiknya bisa membangkitkan semangat dalam belajar. Sungguh, inilah yang sangat penting dan sangat menentukan dalam keberhasilan proses pembelajaran. Sebab, tanpa adanya semanagat, belajar adalah kegitan yang sangat menjemukan. Bila hal ini terjadi, betapa melelahkannya. Dengan demikian, betapa pentingnya semangat dalam belajar.

\section{b. Tanpa Kasih Sayang = Mendidik Kekerasan}

Pendidikan yang di dalamnya tanpa ada kasih sayang sama dengan mendidik kekerasan kepada peserta didik. Sekilas, pernyataan ini terkesan ekstrem. Sebab, tidak ada pendidikan yang secara sengaja mendidik peserta didiknya untuk melakukan tindak kekerasan. Namun, bila hal ini direnungkan sejara jernih, pendidikan yang diselenggarakan tanpa kasih sayang sesungguhnya secara tidak langsung telah mendidik kekerasan kepada peserta didiknya. 


\section{c. Belajar dengan Kasih Sayang Berkesan Sepanjang Zaman}

Peserta didik yang belajar dengan kasih sayang akan mempunyai kesan yang sangat kuat dalam dirinya. Kesan inilah yang membuat ilmu yang dipelajarinya pun menjadi berguna dan bermanfaat dalam kehidupan di masa depan. Sudah, tentu keasan kuat yang dirasakan oleh setiap manusia ada dua macam, yaitu kesan yang baik dan kesan yang buruk. Namun, kecenderungan manusia adalah segera melupakan kesan yang buruk untuk menuju kehidupan yang baik. Namun, tidak demikian dengan kesan yang baik. Seseorang akan menjaga kesannyayang baik, bahkan jika perlu selalu dikenang. ${ }^{10}$

\section{Sabar dalam Mengajar}

Seorang guru yang dicintai oleh anak didiknya adalah yang sabar dalam menghadapi mereka pada saat proses pembelajaran. Kesabaran seorang guru akan membuat peserta didik merasa nyaman dalam belajar. Kesabaran guru juga membuat peserta didik mempunyai waktu yang cukup untuk lebih memahami pelajaran yang dihadapinya. Inilah kunci yang sangat penting dalam meraih keberhasilan di dunia pendidikan, utamanya di lembaga sekolah. Menurut kamus bahasa Indonesia, sabar mempunyai dua makna, yaitu (1) tahan menghadapi cobaan; (2) tenang, tidak tergesa-gesa; tidak terburu nafsu.

Berangkat dari pemahaman kata sabar, seorang guru yang ingin beesikap sabar dalam mengajar dapat melakukan dua hal penting sebgai berikut:

\section{a. Tahan dalam Segala Keadaan}

Menghadapi sikap peserta didik yang tidak sesuai dengan harapan, tidak sedikit guru yang menunjukkan sikap tidak sabar. Sikap anak yang tidak sesuai dengan harapan itu bisa jadi berupa perilaku peserta didik yang tidak memperhatikan pelajaran, melanggar kesepakatan, tidak mengerjakan tugas. Sikap tidak sabar yang demikan biasanya ditunjukan dengan sikap jengkel. Inilah sesungguhnya tipe guru yang tidak tahan dalam menghadapi keadaan peserta ddiknya. Namun, bagi seorang guru yang bisa bersabar tentu akan mendapatkan hasil yang menyenangkan.

\section{b. Tenang dan Tidak Tergesa-gesa}

Seorang guru yang mempunyai sifat sabar dalam mendampingi peserta didiknya tentu akan bersikap tenang atau tidak tergesa-gesa. Hal ini penting sekali agar peserta didik dapat mengikuti proses pembelajaran

\footnotetext{
${ }^{10}$ Akhmad Muhaimin Azzet, Menjadi Guru Favorit, cetakan I (Jogjakarta: Ar-Ruzz Media, 2011), 66.
} 
dengan baik. Sebab, daya tangkap setiap peserta didik, pada saat mendengar penjelasan dari sang guru tentu berbeda anatara yang satu dan yang lainnya. Peserta didik yang hanya diterangkan dengan beberapa kalimat saja langsung sudah bisa memahami apa yang telah disampaikan gurunya. Namun, ada juga peserta didik yang membutuhkan waktu agak lama dibandingkan teman-temannya. Peserta didik yang lambat dalam memahami pelajaran ini tentu harus diperhatikan pula oleh guru. Pada saat yang seperti ini, seorng guru dibutuhkan kesabarannya untuk menjelaskan dengan kalimat-kalimat tambahan atau bahkan pengulangan kepada peserta didiknya. ${ }^{11}$

\section{Bisa Membuat Tertawa}

Guru yang dicintai oleh siswanya adalah guru yang bisa membuat mereka tertawa. Tertawa yang dimaksudkan disini adalah melahirkan rasa gembira atau rasa senang yang berasal dari dalam hati. Sungguh, dalam proses pembelajaran, perlu diselingi dengan tertawa karena hal ini berpengaruh erat dengan kesehatan jiwa siswa dan semangat mereka dalam belajar. Di samping itu, kehadiran guru yang bisa membuat tertawa karena hal ini berpengaruh erat dengan kesehatan jiwa siswa dan semangat mereka dalam belajar. Di samping itu, kehadiran guru yang bisa membuat ketawa juga selalu dirindu oleh siswanya. Bila sudah demikian, proses pembelajaran tentu akan bisa berjalan dengan lebih menyenangkan.

Secara umum, tertawa memang sangat bermanfaat bagi yang melakukannya. Di antara manfaat tertawa adalah bisa membuat keshatan mental seseorang menjadi lebih baik dari sebelumnya. Hal ini bisa tejadi karena dengan ketawa rasa khawatir, cemas atau wawas yang dialami seseorang bisa berkurang atau bahkan bisa hilang sama sekali. Begitu pula dengan stres akibat banyak tugas, menghadapi masalah, atau menanggung beban yang berat, dipercaya tertawa bisa meringankan masalah tersebut. Demikian pula dengan rasa takut yang sedang menghinggapi seseorang bisa hilang karena tertawa.

Tertawa juga dipercaya bisa meningkatkan daya pikir dan kreatifitas seseorang. Termasuk, dalam kaitan ini adalah kemampuan seseorang dalam memecahkan masalah menjadi meningkat setelah tertawa. Hal ini bisa terjadi karena tertawa bisa membuat otak lebih segar dalam berpikir setelah sebelumnyan mengalami penegangan. Maka, tidak heran jika kita sering

\footnotetext{
${ }^{11}$ Akhmad Muhaimin Azzet, Menjadi Guru Favorit, cetakan I (Jogjakarta: Ar-Ruzz Media, 2011), 71.
} 
mendapati orang yang ternyata lebih mudah menyelesaikan tugas-tugasnya setelah ia sejenak tertawa yang disebabkan oleh suatu hal.

\section{Pembebas Bagi Siswanya}

Tugas utama seorang guru adalah membebaskan siswanya. Ya, seorang guru adalah sang pembebas, yakni membebaskan siswa dari kebodohan, ketidaktahuan, keterbelakangan, kelemahan, ketakutan, dan segala hal yang membuat tertinggal demi mewujudkan kehidupan yang lebih baik. Sungguh, tugas membebaskan anak didik dari ketinggalan menuju kemajuan ini adalah tugas yang sangat mulia.

Tugas yang sangat mulia ini jangan sampai ketika dilaksanakan di sekolah yang terjadi adalah kebalikannya. Seorang guru bukannya membebaskan anak didiknya, melainkan malah mengekang dengan beragam bentuk dan cara sehingga siswa tidak bisa tumbuh dan berkembang dengan baik.

Apakah ada seorang guru yang justru mengekang anak didik? Sepintas, memang tidak ada. Tugas seorang guru adalah mengajarkan anak yang sebelunya tidak bisa membaca dan menulis menjadi bisa. Seorang guru juga mengajarkan segala macam ilmu pengetahuan dan berbagai nilai kebaikan dalam kehidupan. Sungguh, ini semua adalah tugas membebaskan siswa dari ketidaktahuannya menjadi pandai dan mengerti. Tidak ada guru yang dalam melaksanakan tugasnya menyalahitugas mulia ini.

Namun, dalam proses pembelajaran, ada saja seorang guru yang memang sungguh-sungguh mengajarkan ilmu pengetahuan kepada siswanya. Akan tetapi, pada saat yang sama, seorang guru tersebut mengekang kreativitas siswa dengan banyak larangan. Dalam hal ini, bukan berarti penulis anti larangan. Penulis sangat setuju bila larangan itu diterapkan karena memang demikianlah yang dilarang dalam agama, norma atau tata nilai yang telah diakui bersama dalam kehidupan bermasyarakat. Namun, jika larangan itu hanya karena kepentingan tertentu dan bukan demi kemajuan pendidikan, sudah tentu hal ini sangat perlu untuk dipertanyakan.

\section{Bisa Menjadi Pendengar dan Penengah}

Guru yang dicintai siswa adalah guru yang bisa menjadi pendengar dan penengah bagi mereka. Mendengar dimaksudkan di sini lebih kepada upaya seorang guru untuk bisa memberikan waktunya kepada siswanya yang sedang menyampaikan pikiran maupun perasaannya. Hal ini merupakan kebutuhan setiap manusia, termasuk siswa, yakni didengarkan apa yang ingin disampaikannya. Sedangkan, menjadi penengah bermakna bagaimana seorang 
guru bisa menempatkan dirinya secara netral (tidak memihak) apabila ada dua siswa atau siswa dengan pihak lain terjadi ketidakcocokan. ${ }^{12}$

\section{Kesimpulan}

Menjadi guru adalah pekerjaan yang sungguh mulia. Ia bertanggung jawab tidak hanya menjadikan para anak manusia pandai di bidang ilmu pengetahuan, tetapi juga bermoral baik dalam kehidupan ini. Seorang anak manusia yang pada mulanya tidak mengerti apa-apa, di hadapan seorang guru dididik untuk memahami kehidupan secara lebih baik dan mengenal dunia. Di pundaknyalah ada tugas dan tanggung jawab keberlangsungan masa depan generasi yang lebih cerdas dan berperadapan.

Begitu mulia pekerjaan seorang guru sekaligus betapa berat tugas dan tanggung jawab menjadi seorang guru. Inilah mengapa tidak semua orang bisa menjadi seorang guru yang berhasil. Hanya orang-orang tertentu yang mempunyai rasa cinta terhadap anak-anak atau peserta didik dan berdedikasi tinggi terhadap dunia pendidikan saja yang mampu menjadi seorang guru. Inilah pribadi seorang guru yang berhasil mengajar sekaligus mendidik di hadapan murid-muridnya, sosok seorang guru favorit yang dicintai oleh anak didiknya.

Motivasi dan kecintaan seseorang untuk menjadi guru adalah dasar bagi seorang guru akan sukses dan dicintai oleh murid-muridnya atau tidak. Motivasi dan kecintaan ini harus terpancang sejak awal seseorang menekuni profesi sebagai guru atau bisa pula baru terbangunkan setelah seseorang menjalani profesi ini sekian waktu. Motivasi dan kecintaan ini harus senantiasa dijaga agar seorang tetap bersemangat menghadapi anak didiknya dalam proses pembelajaran.

Sepuluh faktor agar menjadi guru yang dicintai oleh siswanya, yaitu sebagai berikut:

1. Dekat dengan anak didik

2. Membangun suasana yang menyenangkan

3. Bisa berperan sebagai orangtua kedua

4. Menjadi sahabat dalam belajar

5. Berkepribadian layak ditiru

6. Bersikap kasih sayang

7. Sabar dalam mengajar

8. Bisa membuat tertawa

9. Pembebas bagi siswanya

\footnotetext{
${ }^{12}$ Akhmad Muhaimin Azzet, Menjadi Guru Favorit, cetakan I (Jogjakarta: Ar-Ruzz Media, 2011), 89.
}

Dirasah, Vol. 3, No. 1, Februari 2020 


\section{$54 \mid$ Yazidul Busthomi}

10. Bisa menjadi pendengar dan penengah.

\section{Daftar Pustaka}

Azzet, Akhmad Muhaimin . Menjadi Guru Favorit. Cetakan I. Jogjakarta: Ar-Ruzz Media. 2011.

Ismail. Strategi Pembelajaran Agama Islam Berbasis PAIKEM.Cetakan IV. Semarang: Rasail Media Group. 2009.

Majid, Abdul . Perencanaan Pembelajaran. Cetakan VI. Bandung: PT Remaja Rosdakarya. 2009.

Syah, Muhibbin . Psikologi Pendidikan dengan Pendekatan Baru. Cetakan XIIII. Bandung: PT Remaja Rosdakarya. 2008.

Usman, Moh. Uzer . Menjadi Guru Profesional. Cetakan XX111. Bandung: PT Remaja Rosdakarya. 2009.

Zuhairini . Filsafat Pendidikan Islam. Cetakan II. Jakarta: Bumi Aksara. 2005.

Copyright @ 2020 Journal Dirasah: Vol. 3, No. 1, Februari 2020, p-ISSN: 2615-0212, e-ISSN;

2621-2838

Copyright rests with the authors

Copyright of Jurnal Dirasah is the property of Jurnal Dirasah and its content may not be copied oremailed to multiple sites or posted to a listserv without the copyright holder's express writtenpermission. However, users may print, download, or email articles for individual use.

https://ejournal.iaifa.ac.id/index.php/dirasah 